\title{
Proteomics in Medicine
}

\section{Margaret Simonian*}

Department of Biological Chemistry, David Geffen School of Medicine, Charles E Young Drive East, USA

Corresponding author: Margaret Simonian, Department of Biological Chemistry, David Geffen School of Medicine, Charles E Young Drive East, USA, E-mail: margaret@chem.ucla.edu

Received date: July 25, 2016; Accepted date: July 28, 2016; Published date: July 31, 2016

Copyright: @ 2016 Simonian M. This is an open-access article distributed under the terms of the Creative Commons Attribution License, which permits unrestricted use, distribution, and reproduction in any medium, provided the original author and source are credited.

Citation: Simonian M (2016) Proteomics in Medicine. J Data Mining Genomics Proteomics 7: e126. doi:10.4172/2153-0602.1000e126

\section{Editorial}

Proteomics is the identification of proteins in a tissue or cell, and the determination of their function, structure and modifications [1,2]. The term proteome was coined by Marc Wilkins to describe all the proteins expressed by a genome [1]. It is considered to be the next step in modern biology. Proteomics is dynamic compared to genomics because it changes constantly to reflect the cell's environment. The main objectives in the field of proteomics are: (i) Identify all proteins; (ii) Analyse differential protein expression in different samples; (iii) Characterise proteins by identifying and studying their function and cellular localisation; and (iv) Understand protein interaction networks.

Proteomics relies on; successful protein separation and purification techniques, mass spectrometry analysis, bioinformatics, and gene and protein databases. Sample preparation is the most critical and challenging task in any successful proteomics project [3]. Isolation of proteins involves releasing proteins by breaking the cell wall and solubilising the proteins in a buffer for fractionation and analysis [4]. Isolation methods can vary from simple solubilisations to more complex extractions based on the tissue and cell types. The difficulties involving in the purification methods and recovery of protein are the major obstacles to characterization assays, especially of low abundance proteins such as membrane proteins [5].

Proteomics plays an important role in medical research, such as in drug discovery and diagnostics, because of the link between proteins, genes and diseases [6]. Understanding protein functions help to understand diseases, most current drugs are either proteins or they target specific proteins in the body [7]. Identifying unique protein expression associated with specific diseases is a very important and promising area in the field of clinical proteomics [6]. Neuroproteomics is a rising application in the study of brain disorders. Proteomics analysis of brain tissue is an essential part of neuroscience research [8-10], although it faces many challenges, most importantly the difficulty of obtaining sufficient sample for mass spectrometry analysis, which requires at least $30 \mathrm{ng}$ of protein. Usually $30-40 \%$ of proteins are lost during the sample preparation process, therefore low abundance proteins will not always be detected $[11,12]$. The availability of animal models may solve these problems in some cases [11].
Quantitative labelled and label free proteomics technologies contributes to studies aimed at revealing disease pathways, biomarker discovery and drug development [12]. The continuous advancement in these technologies promises the fast and better analysis of proteins, understanding their function and role in many important diseases such as Alzheimer's and Parkinson's.

\section{References}

1. Wilkins MR, Williams KL, Appel RD, Hochstrasser DF (1997) Proteome Research: New Frontiers in Functional Genomics (Principles and Practice), Kindle Edition, Springer-Verlag, New York.

2. Baxevanis AD, Ouellette BF (2005) Bioinformatics: A Practical Guide to the Analysis of Genes and Proteins (3rd edn.) John Wiley, Hoboken, New Jersey.

3. Hall J, Morton I (1999) Concise dictionary of pharmacological agents: properties and synonyms. Kluwer Academic 255: 5521-5524.

4. Kulakowska AB, Krzysik BA, Dylag T (2007) Methods for samples preparation in proteomic research. J Chromatogr B Analyt Technol Biomed Life Sci 849: 1-31.

5. Carlas B, Pineiro C, Calvo E, Lopez-Ferrer D, Gallardo J (2007) Trends in sample preparation for classical and second generation proteomics. J Chromatogr 153: 235-258.

6. Simonian M (2015) Cerebral Arteriovenous Malformations (AVMs): Causes, Treatment and Research. MOJPB 2: 5.

7. Wulfkuhle D, Liotta A, Petricoin F (2003) Early detection: Proteomic applications for the early detection of cancer. Nat Rev Cancer 3: 267-275.

8. Barkhoudarian G, Whitelegge JP, Kelly DF, Simonian M (2016) Proteomics analysis of brain meningiomas in pursuit of novel biomarkers of the aggressive behavior. J Proteomics and Bioinformatics 9: 53-57.

9. Simonian M, Loo RRO, Loo JA, Stoodley MA, Molloy MP (2014) Proteomics Detection of Endothelial Cell Surface Proteins Following Irradiation as Potential Targets for Brain Arteriovenous Malformations Molecular Therapy. MOJPB 1: 1.

10. Simonian M, Molloy MP, Stoodley MA (2012) In vitro and in vivo biotinylation of endothelial cell surface proteins in the pursuit of targets for vascular therapies for brain AVMs. Metabolomics 1.

11. Ball HC, Roulhac L (2010) Multidimensional Techniques in Protein Separations for Neuroproteomics. Neuroproteomics. Boca Raton.

12. Butcher J (2007) Neuroproteomics comes of age. Lancet Neurol 6: 850. 